\title{
PENGARUH LAMA FERMENTASI TERHADAP KADAR ALKOHOL TAPE SINGKONG (Manihot utilissima Pohl).
}

\author{
Hafidatul Hasanah, Akyunul Jannah, A. Ghanaim Fasya \\ Jurusan Kimia, Fakultas Sains dan Teknologi, UIN Maulana Malik Ibrahim Malang
}

\begin{abstract}
Tape is one of the products of fermentation. Of the agreement MUI, foods and beverages containing alcohol should not exceed $1 \%$, so the food / drinks that contain high levels of alcohol exceeding $1 \%$ are included in the category of haram for consumption. This study aimed to determine the effect of fermentation time on ethanol content of cassava (Monihot utilissima Pohl) tapai. The method that is used to separate the two or more component of volatile and non volatile from tapai is called distillation while to analyze an ethanol level used gas chromatography (GC) method. To examine the data which differentiate the base concentration of alcohol (\%) in cassava tapai since fermentation

process which were analyzed by variants analysis (ANOVA). In the next experiment, if there was different significant result, then continued by the test of BNT which the level for about $1 \%$.

The samples of cassava (Monihot utilissima Pohl) tapai fermented for about 24, 48, 72, 96 and 120 hours. Those tapai were mashed and added the aquades. The mixed materials were distillated, then entered into the bottle and considered as gram unit. The considered distillations were being analyzed used gas chromatography (GC) method.The result of the research showed that there is the influence of long fermentation to ethanol level's of cassava (Manihot utilissima Phol) tapai. The level of cassava ethanol was $0.844 \%, 2.182 \%$, $4.904 \%, 6.334 \%$ and $11.811 \%$. The long fermentation was for about 120 hours and it was an indeed influence (p $<0,01)$ to the level of cassava's ethanol among the period of long fermentation.
\end{abstract}

Key words : fermentation, alcohol levels,tapes

\section{ABSTRAK}

Tape merupakan salah satu produk hasil fermentasi. Dari hasil kesepakatan MUI, makanan dan minuman yang mengandung alkohol tidak boleh melebihi $1 \%$, sehingga makanan/minuman yang mengandung kadar alkohol melebihi $1 \%$ termasuk dalam katagori haram untuk dikonsumsi. Penelitian ini bertujuan untuk mengetahui pengaruh lama fermentasi terhadap kadar alohol tape singkong (Monihot utilissima Pohl). Metode yang digunakan untuk memisahkan dua atau lebih komponen volatil dan non volatil dari tape adalah metode destilasi, untuk analisis kadar etanol menggunakan metode kromatografi gas (GC). Data yang diperoleh dianalisis dengan analisis varians (ANOVA) untuk menguji adanya perbedaan konsentrasi kadar (\%) akohol tape singkong selama fermentasi. Apabila terjadi perbedaan yang signifikan maka dilanjutkan dengan uji BNT dengan taraf $1 \%$.

Pada penelitian ini sampel tape singkong yang telah difermentasi selama 24 jam, 48 jam, 72 jam, 96 jam dan 120 jam ditumbuk sampai halus dan ditambah aquades. Campuran yang diperoleh didestilasi, destilat yang dihasilkan dimasukkan dalam botol dan ditimbang dengan satuan gram. Destilat yang sudah ditimbang dianalisis menggunakan metode kromatografi gas. Hasil penelitian menunjukkan bahwa ada pengaruh lama fermentasi terhadap kadar alkohol tape singkong. Kadar alohol tape singkong berturut-turut sebesar $0.844 \%$, $2.182 \%, 4.904 \%, 6.334 \%$, dan $11.811 \%$. Lama fermentasi 120 jam berpengaruh sangat nyata $(\mathrm{p}<0,01)$ pada kadar alkohol tape singkong di antara lama fermentasi lainnya.

Kata kunci : fermentasi, kadar alkohol,tape

\section{PENDAHULUAN}

Islam telah memberikan batasan terhadap jenis makanan dan minuman yang halal untuk dikonsumsi, seperti sudah ditegaskan dalam firman Allah dalam Surat
Al-Maaidah ayat 88: " Dan makanlah makanan yang halal lagi baik dari apa yang telah Allah rezekikan kepadamu, dan bertakwalah kepada Allah yang kamu beriman kepada-Nya" 
Ayat di atas dengan tegas telah memerintahkan kita untuk memakan makanan yang halal dan toyyib. Halal dan toyyib adalah dua kesatuan yang tidak bisa dipisahkan, yang dapat diartikan halal dari segi syariah dan toyyib dari segi kesehatan, gizi, estetika dan lainnya. Tetapi, masih banyak masyarakat yang salah kaprah menanggapi makanan yang halal dan toyyib, seperti minuman khamer. Kebanyakan makanan dan minuman yang diharamkan mengandung alkohol. Makanan dan minuman yang berasal dari proses fermentasi menghasilkan alkohol. Contohnya tape.

Tape adalah produk yang dihasilkan dari proses fermentasi, di mana terjadi suatu perombakan bahan-bahan yang tidak sederhana. Zat pati yang ada dalam bahan makanan diubah menjadi bentuk yang sederhana yaitu gula, dengan bantuan suatu mikroorganisme yang disebut ragi atau khamir.

Ragi tape adalah bahan yang dapat digunakan dalam pembuatan tape, baik dari singkong dan beras ketan. Menurut Dwijoseputro dalam Tarigan (1988) ragi tape merupakan populasi campuran yang tediri dari spesies-spesies genus Aspergilius, Saccharomyces, Candida, Hansenulla, dan bakteri Acetobacter. Genus tersebut hidup bersama-sama secara sinergis. Aspergillus menyederhanakan tepung menjadi glukosa serta memproduksi enzim glukoamilase yang akan memecah pati dengan mengeluarkan unit-unit glukosa, sedangkan Saccharomyces, Candida dan Hansenulla dapat menguraikan gula menjadi alkohol dan bermacam-macam zat organik lain sementara itu Acetobacter dapat merombak alkohol menjadi asam. Beberapa jenis jamur juga terdapat dalam ragi tape, antara lain Chlamydomucor oryzae, Mucor sp, dan Rhizopus sp.

Menurut Wanto dan Arif Subagyo dalam Maimuna, S (2004) Khamir merupakan fungi bersel tunggal sederhana, kebanyakan bersifat saprofitik dan biasanya terdapat dalam tumbuh-tumbuhan yang mengandung karbohidrat. Khamir dapat diisolasi dari tanah yang berasal dari kebun anggur, kebun buah-buahan dan biasanya khamir berada di dalam cairan yang mengandung gula, seperti cairan buah, madu, sirup, dan sebagainnya. Bentuk sel khamir biasanya bulat, oval, dan biasanya tidak mempunyai flagella. Pada umumnya khamir berkembang biak dengan bertunas, membelah diri dan pembentukan spora.

Khamir mempunyai kemampuan untuk memecah pangan karbohidrat menjadi alkohol dan karbondioksida. Proses ini diketahui sebagai fermentasi alkohol yaitu proses anaerob. Khamir mempunyai sekumpulan enzim yang diketahui sebagai zymase yang berperan pada fermentasi senyawa gula, seperti glukosa menjadi etanol dan karbondioksida. Reaksi yang terjadi dalam fermentasi alkohol sebagai berikut:

$$
\begin{array}{ll}
\mathrm{C}_{6} \mathrm{H}_{12} \mathrm{O}_{6} & \rightarrow \underset{\text { Glukosa }}{2 \mathrm{C}_{2} \mathrm{H}_{5} \mathrm{OH}}+\underset{\text { Etanol }}{2 \mathrm{CO}_{2}} \text { karbondioksida }
\end{array}
$$

Jika pemberian $\mathrm{O}_{2}$ berlebihan, sel khamir akan melakukan respirasi secara aerobik, dalam keadaan ini enzim khamir dapat memecah senyewa gula lebih sempurna, dan akan dihasilkan karbondioksida dan air.

$\mathrm{C}_{6} \mathrm{H}_{12} \mathrm{O}_{5}+6 \mathrm{O}_{2} \longrightarrow 6 \mathrm{CO}_{2}+6 \mathrm{H}_{2} \mathrm{O}$

Glukosa oksigen karbondioksida air

Jenis khamir yang biasanya dipakai dalam indutri fermentasi alkohol adalah jenis Saccharomyces cereviseae. Saccharomyces cereviseae berbentuk bulat, oval, atau memanjang, dan mungkin berbentuk pseudomiselium. Reproduksi khamir dilakukan dengan cara pertunasan multipolar, atau melalui pembentukan askospora. Askospora dapat terbentuk setelah terjadi konjugasi, atau berasal dari sel diploid.

Pertumbuhan sel merupakan puncak aktivitas fisiologi yang saling mempengaruhi secara berurutan. Proses pertumbuhan ini sangat kompleks meliputi pemasukan nutrien dasar dari lingkungan ke 
dalam sel, konversi bahan-bahan nutrien menjadi energi dan berbagai constituent vital cell serta perkembangbiakan. Pertumbuhan mikrobial ditandai dengan peningkatan jumlah dan massa sel serta kecepatan pertumbuhan tergantung pada lingkungan fisik dan kimia (Anonymous, 2008). Adapun kurva pertumbuhan mikroba secara umum dapat dilihat pada Gambar 1 .

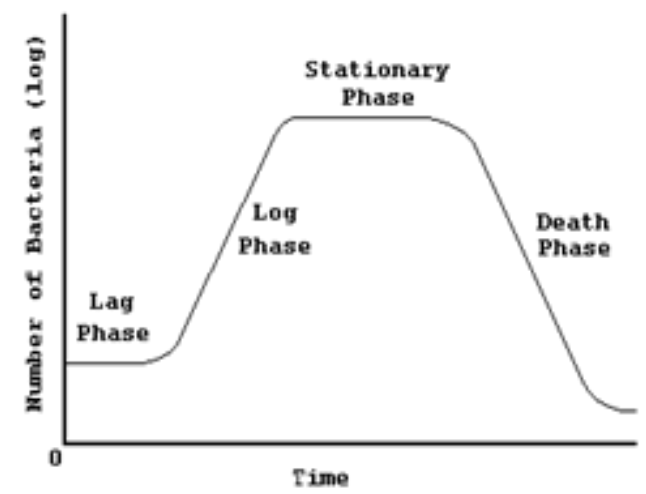

Gambar 1. Kurva Pertumbuhan Mikroba

Pada dasarnya pertumbuhan sel mikroba dapat berlangsung tanpa batas, akan tetapi karena pertumbuhan sel mikroba berlangsung dengan mengkonsumsi nutrien sekaligus mengeluarkankan produk-produk metabolisme yang terbentuk, maka setelah waktu tertentu laju pertumbuhan akan menurun dan akhirnya pertumbuhan berhenti sama sekali. Berhentinya pertumbuhan dapat disebabkan karena berkurangnya beberapa nutrien esensial dalam medium atau karena terjadinya akumulasi aututuksin dalam medim atau kombinasi dari keduanya (Ansori, A., 1989).

Saccharomyces cerevisiae merupakan spesies yang bersifat fermentatif kuat. Tetapi dengan adanya oksigen, Saccharomyces cerevisiae juga dapat melakukan respirasi yaitu mengoksidasi gula menjadi karbondioksida dan air. Kedua sistem tersebut menghasilkan energi, meskipun yang dihasilkan dari respirasi lebih tinggi dibandingkan dengan melalui fermentasi (Fardiaz, S., 1992).
Saccharomyces cerevisiae akan mengubah $70 \%$ glukosa di dalam substrat menjadi karbondioksida dan alkohol, sedangkan sisanya tanpa ada nitrogen diubah menjadi produk penyimpanan cadangan. Produk penyimpanan tersebut akan digunakan lagi melalui proses fermentasi endogenous jika glukosa di dalam medium sudah habis (Fardiaz, S., 1992)

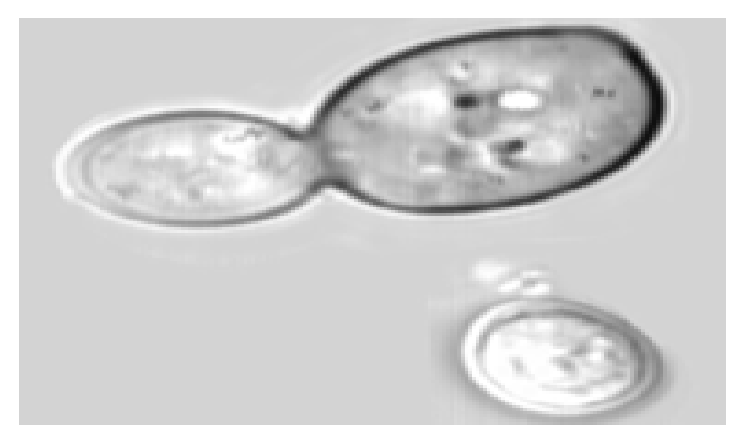

Gambar 2. Saccharomyces cereviseae

Saccharomyces cereviseae adalah jenis khamir utama yang berperan dalam produksi minuman beralkohol seperti bir, anggur, dan juga digunakan untuk fermentasi adonan dalam perusahaan roti dan fermentasi tape. Kultur yang dipilih harus dapat tumbuh dengan baik dan mempunyai toleransi yang tinggi terhadap alkohol serta mampu menghasilkan alkohol dalam jumlah banyak (Irianto, K., 2006).

Pada hakekatnya semua makanan yang mengandung karbohidrat bisa diolah menjadi tape. Tetapi sampai sekarang yang sering diolah adalah ketan dan singkong (berdaging putih atau kuning). Singkong adalah pohon tahunan tropika dan subtropika dari keluarga Euphorbiaceae. Umbinya dikenal luas sebagai makanan pokok penghasil karbohidrat dan daunnya sebagai sayuran. Adapun Singkong dapat diklasifikasikan sebagai berikut (Deputi Menegristek Bidang Pendayagunaan dan Pemasyarakatan Ilmu Pengetahuan dan Teknologi, 2005): 


$\begin{array}{lll}\text { Kerajaan } & : \text { Plantae } \\ \text { Divisio } & : \text { Spermatophyta } \\ \text { Kelas } & : \text { Dicotyledoneae } \\ \text { Ordo } & : \text { Euphorbiales } \\ \text { Familia } & : \text { Euphorbiaceae } \\ \text { Genus } & : \text { Manihot } \\ \text { Spesies } & : \text { M. esculenta } \\ \text { Nama } & : \text { Manihot esculenta Crantz } \\ \text { binomial } & & \end{array}$

Singkong mempunyai komposisi kandungan kimia (per 100 gram) dapat dilihat pada Tabel 1 (Anonymous, 2007).

Tabel 1. Komposisi kandungan kimia singkong (per 100 gram)

\begin{tabular}{|l|c|}
\hline \multicolumn{1}{|c|}{ Kandungan Kimia } & Jumlah \\
\hline Kalori & $146,00 \mathrm{kal}$ \\
\hline Protein & 1,20 gram \\
\hline Air & $62,50 \mathrm{gram}$ \\
\hline Phospor & $40,00 \mathrm{mg}$ \\
\hline Karbohidrat & $38,00 \mathrm{gram}$ \\
\hline Lemak & 0,30 gram \\
\hline Hidrat arang & 34,7 gram \\
\hline Kalsium & $33,00 \mathrm{mg}$ \\
\hline Zat besi & $0,7 \mathrm{mg}$ \\
\hline Vitamin B1 & $0,06 \mathrm{mg}$ \\
\hline
\end{tabular}

Sumber : Deputi Menegristek Bidang

Pendayagunaan dan Pemasyarakatan Ilmu

Pengetahuan dan Teknologi

Singkong merupakan sumber energi yang kaya karbohidrat namun sangat miskin protein. Sumber protein yang bagus justru terdapat pada daun singkong karena mengandung (per 100 gram) : Vitamin A 11000 SI, Vitamin C 275 mg, Vitamin B1 0,12 mg, Kalsium $165 \mathrm{mg}$, Kalori $73 \mathrm{kal}$, Fosfor $54 \mathrm{mg}$, Protein 6,8 gram, Lemak 1,2 gram, Hidrat arang 13 gram, Zat besi $2 \mathrm{mg}$, asam amino metionin dan $87 \%$ bagian daun dapat dimakan. Buah singkong mengandung (per 100 gram) : Vitamin B1 $0,06 \mathrm{mg}$, Vitamin C $30 \mathrm{mg}$ dan $75 \%$ bagian buah dapat dimakan. Sedangkan Kulit batang singkong mengandung tanin, enzim peroksidase, glikosida dan kalsium oksalat (Anonymous, 2007).

Proses fermentasi tape singkong harus dilakukan secara optimal. Selain memilih bahan dasar singkong yang baik, proses pembuatan tape singkong harus benar. Ragi yang digunakanpun harus bermutu tinggi, karena ragi merupakan bahan utama dalam proses pembuatan tape. Kesterilan ragi dan bahan dasar pembuatan tape singkong ketika akan digunakan sangat penting.

Hal ini bertujuan agar tidak dicemari bakteri lain. Karena jika dalam proses pembuatan tape singkong dicemari bakteri lain maka proses fermentasi akan terhambat. Sehingga tape akan mengeluarkan bakteri yang sering mengeluarkan racun yang berbahaya bagi kesehatan manusia.

Dari hasil penelitian S. Siembenhandl L.N., Lestario, D., Trimmel and E. Berghofer yang dilaporkan di jurnal ilmiah international Journal of Food Sciences and Nutrion volume 52 halaman 347-357 pada tahun 2001 menyebutkan hasil kadar etanol pada tape ketan hitam setelah didiamkan selama 2.5 hari (60 jam) dengan pembuatan tape secara tradisional mencapai $3.380 \%$. Dari data tersebut terlihat bahwa setelah 2.5 hari (60 jam) kadarnya mencapai $3.3 \%$, jika lebih dari 3 hari bisa dibayangkan berapa persen kadar etanol yang akan dicapai (Apriyantono, 2005).

Penjual tape biasanya membuat tape dengan lama fermentasi 3 hari sampai 7 hari bahkan lebih. Padahal di dalam salah satu hadist yang menceritakan waktu Rasulullah tidak mau minum jus yang dibiarkan dalam suhu ruang lebih dari 3 hari. Setelah dilakukan tes menghitung kadar alkoholnya, kadar alkohol yang didapat sebanyak $1 \%$. Dengan adanya patokan $1 \%$ ini, maka akan mudah bagi kita untuk memilih dan menentukan apakah suatu produk makanan/minuman bisa dikatakan berpotensi memabukkan seperti minuman keras (khamar) atau tidak.

Berangkat dari permasahan di atas, maka perlu dilakukan penelitian tentang Pengaruh Lama Fermentasi Terhadap Kadar Alkohol Tape Singkong (Manihot utilissima Pohl). 


\section{METODE PENELITIAN}

\section{Bahan:}

$\begin{array}{lccr}\text { Singkong, } & \text { ragi } & \text { merk } & \text { NKL, } \\ \text { etanol/ } \mathrm{CH}_{3} \mathrm{CH}_{2} \mathrm{OH} & \text { a.h } \\ \text { alumunium foil, aquades. }\end{array}$

Alat:

Erlenmeyer $250 \mathrm{~mL}$, labu ukur 100 $\mathrm{mL}$, pipet volum $25 \mathrm{~mL}$, pipet volum $1 \mathrm{~mL}$, pipet ukur $2 \mathrm{~mL}$ sampai $5 \mathrm{~mL}$, timbangan analitik, gelas ukur, gelas arloji, mortar, seperangkat alat destilasi, seperangkat alat kromatografi gas (GC) merk $h p$ Newlett Packard $5890^{\circ}\left(3390^{\circ}\right.$ integrator) dengan menggunakan fase gerak $\mathrm{He}$, kolom porapak dan detektor TCD, kompor, dandang, loyang, sendok, plastik, ember.

\section{Proses Pembuatan Tape singkong}

Singkong dikupas kulitnya sampai bersih. Ditimbang \pm 500 gram singkong dan disortasi. Singkong di tanak selama \pm 30 menit. Setelah matang, diangkat dan didinginkan pada suhu ruangan selama \pm 1 jam.

Singkong yang sudah matang ditimbang dengan berat 100 gram sebanyak 5 kali/sampel. Masing-masing sampel diberi ragi sebanyak 0,85 gram/sampel. Singkong yang sudah ditaburi ragi dibungkus dengan plastik, kemudian diikat rapat dengan karet dan disimpan selama 24 jam, 48 jam, 72 jam, 96 jam dan 120 jam pada suhu kamar. Mengulang tiap perlakuan diatas hingga didapatkan 3 kali ulangan.

\section{Destilasi Alkohol Pada Tape singkong}

Ditimbang 25 gram tape ketan hitam atau tape singkong dan ditumbuk sampai halus. Ditambah $25 \mathrm{~mL}$ aquades. Campuran dimasukkan dalam labu alas bulat dan labu destilat dipasang pada alat destilasi dan ditetapkan pada suhu $78{ }^{0} \mathrm{C}-100{ }^{\circ} \mathrm{C}$.

Didestilasi dan destilat hasil destilasi ditampung dalam tempat terpisah. Destilasi dihentikan jika sudah tidak ada destilat yang menetes dalam penampung. Destilat yang didapat ditimbang dalam satuan gram, lalu dimasukkan dalam botol kecil dengan ukuran $10 \mathrm{ml}$ dan ditutup rapat. Destilat yang disimpan dalam botol siap untuk dianalisis dengan menggunakan kromatografi gas (GC).

\section{Pembuatan Kurva Baku Etanol}

Dibuat seri konsentrasi $1 ; 3 ; 5 ; 7$; dan $9 \%$. $1 \mu \mathrm{l}$ dari masing-masing konsentrasi disuntikkan ke dalam kolom. Luas puncak etanol dari kromatogram dihitung. Kurva baku dibuat dengan memplotkan rasio luas puncak etanol dengan kadar etanol (\% v/v). Persamaan kurva baku dengan regresi linear.

\section{Analisis Kadar Etanol Dengan Kromatografi Gas (GC)}

Diambil (1 $\mu \mathrm{l})$ dari masing-masing larutan singkong dan disuntikkan ke dalam kolom melalui tempat injeksi. Luas puncak etanol dari kromatogram dihitung. Kadar etanol tape singkong ditentukan dengan menggunakan persamaan kurva baku.

\section{Teknik Analisi Data}

Data yang telah di peroleh dalam hasil penelitian ini dianalisis dengan analisis varians (ANOVA) untuk menguji adanya perbedaan konsentrasi kadar (\%) etanol tape singkong selama fermentasi. Apabila terjadi perbedaan yang signifikan maka dilanjutkan dengan uji BNT dengan taraf $1 \%$.

\section{HASIL DAN PEMBAHASAN}

\section{Pembuatan Tape Singkong}

Proses fermentasi tape singkong harus dilakukan secara optimal. Selain memilih bahan dasar singkong yang baik, proses pembuatan tape singkong harus benar. Ragi yang digunakanpun harus bermutu tinggi, karena ragi merupakan bahan utama dalam proses pembuatan tape. Kesterilan ragi dan bahan dasar pembuatan tape singkong ketika akan digunakan sangat penting. Hal ini bertujuan agar tidak dicemari bakteri lain. Karena jika dalam proses pembuatan tape singkong dicemari bakteri lain maka proses fermentasi akan terhambat. Sehingga tape akan mengeluarkan bakteri yang sering 
mengeluarkan racun yang berbahaya bagi kesehatan manusia.

Tape singkong dibuat dengan komposisi singkong (media) dan ragi adalah $10: 0,085$. Ragi yang digunakan adalan ragi merk NKL yang biasa digunakan dipasaran. Campuran singkong (media) dan ragi dibungkus rapat, lalu disimpan selama 24 jam, 48 jam, 72 jam, 96 jam dan 120 jam pada suhu kamar.

Proses pembungkusan dan penyimpanan ini dilakukan karena proses fermentasi tape menggunakan proses fermentasi anaerob. Tape yang melalui fermentasi anaerob ini rasanya akan lebih manis dibandingkan dengan tape hasil fermentasi aerob, mikroba-mikroba yang terkandung di dalam ragi ini tidak dapat melakukan aktivitasnya dengan sempurna (Tarigan, 1988).

Secara singkat perubahan biokimia selama fermentasi tape dapat ditulis sebagai berikut (Kuswanto dan Sudarmadji (1987) dalam Hambali (2001)):

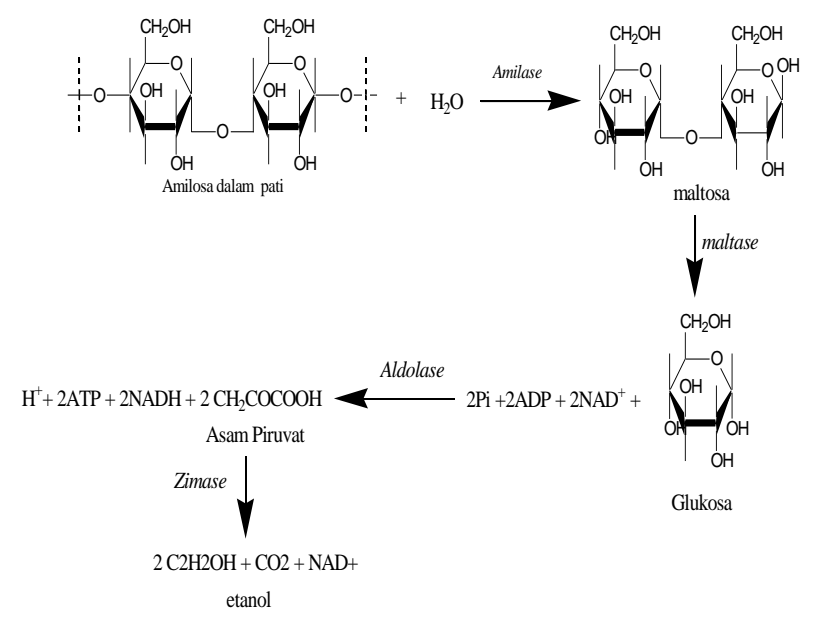

Gambar 3. Reaksi Fermentasi Alkohol Tape Singkong

Mula-mula pati dalam singkong akan diubah oleh enzim amilase yang dikeluarkan oleh mikroba tersebut menjadi maltosa. Maltosa dapat dirombak menjadi glukosa oleh enzim maltase. glukosa oleh enzim zimase dirombak menjadi alkohol. Alkohol yang dihasilkan dari proses fermentasi tape singkong kemudian dianalisis dengan menggunakan metode kromatografi gas (GC).

Pada fermentasi tape yang lebih lanjut alkohol oleh enzim alkoholase dapat diubah menjadi asam asetat, asam piruvat dan asam laktat. Terbentuknya asam asetat, asam piruvat dan asam laktat karena adanya bakteri Acetobacter yang sering terdapat dalam ragi yang bersifat oksidatif.

Buckle et.all (1985), menyatakan bahwa asam piruvat adalah produk yang terbentuk pada hidrolisis glukosa menjadi etanol. Asam piruvat dapat diubah menjadi etanol dan asam laktat. Asam-asam organik dari alkohol membentuk ester aromatik sehingga tape memiliki cita rasa yang khas.

Pada umumnya proses pembutan tape menggunakan proses fermentasi anaerob, yaitu setelah bahan diragikan, dan dimasukkan kedalam kantong plastik atau dapat juga menggunakan daun pisang kemudian disimpan ditempat tertutup selama $\pm 2-3$ hari pada temperatur $26-28{ }^{\circ} \mathrm{C}$. Tape yang melalui fermentasi anaerob ini rasanya akan lebih manis dibandingkan dengan tape hasil fermentasi aerob, mikroba-mikroba yang terkandung di dalam ragi ini tidak dapat melakukan aktivitasnya dengan sempurna (Tarigan, 1988).

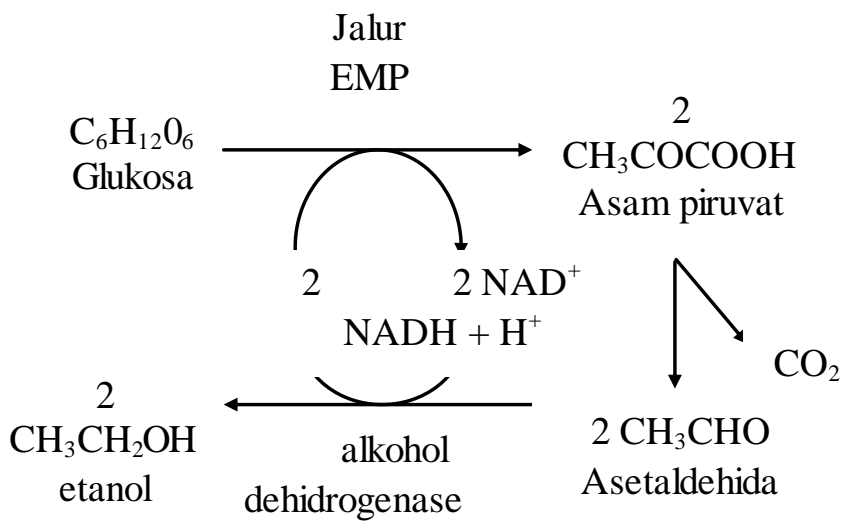

Gambar 3. Skema jalur fermentasi alkohol oleh khamir

Pada proses fermentasi anaerob mula-mula glukosa dipecah menjadi asam piruvat yang melalui lintasan Embden Meyerhoff Pamas (EMP). Setelah itu terjadi dekarboksilasidehida asam piruvat menjadi 
asetaldehida. asetaldehida tereduksi menjadi etanol yaitu menerima elektron hasil oksidasi asam gliseraldehida 3phosphat. Melalui proses fermentasi anaerob ini $90 \%$ glukosa akan dirubah menjadi etanol dan $\mathrm{CO}_{2}$ (Ansori, R., 1989).

\section{Destilasi Alkohol Pada Tape Singkong}

Dalam kimia, sering dihadapi masalah yang berhubungan dengan cara memisahkan solute atau solvent dari larutannya. Jika solute bukan volatil atau kurang volatil dibandingkan solventnya maka, solvent dapat dipisahkan dengan destilasi. Dasar pemisahan destilasi adalah perbedaan dua titik didih dua cairan atau lebih. Jika campuran dipanaskan maka komponen yang titik didihnya lebih rendah akan menguap lebih dulu. Dengan megatur sushu secara cermat komponen larutan akan menguap dan mengembunkan komponen demi komponen secara bertahap. Proses pengembunan terjadi dengan mengalirkan uap ke tabung pendingin.

Adapun tahapan metode destilasi adalah ditimbang 25 gram tape dan ditumbuk sampai halus dengan menggunakan mortar. Penumbukan tape bertujuan untuk memudahkan etanol yang terkandung pada tape untuk menguap. Ditambah $25 \mathrm{~mL}$ aquades. Campuran tesebut dimasukkan dalam labu alas bulat dan labu destilat dipasang pada alat destilasi dan ditetapkan pada suhu normal etanol dan air yaitu $78{ }^{\circ} \mathrm{C}-100{ }^{\circ} \mathrm{C}$.

Didestilasi, pada proses ini senyawa yang menguap terlebih dahulu adalah etanol dan air karena mempunyai titik didih paling rendah yaitu $\quad 78{ }^{0} \mathrm{C}$ dan $100{ }^{0} \mathrm{C}$ dibandingkan dengan senyawa-senyawa yang lain seperti glukosa dengan titik didik $146{ }^{0} \mathrm{C}$, dan asam asetat dengan titik didik $118,1{ }^{\circ} \mathrm{C}$. Uap etanol yang keluar dari labu alas bulat akan keluar melewati pipa L dan diembunkan kembali dengan pendingin/kondensor, destilat yang sudah diembunkan ditampung dalam tempat terpisah. Destilasi dihentikan jika sudah tidak ada destilat yang menetes dalam penampung.
Destilat yang didapat ditimbang dalam satuan gram, lalu dimasukkan dalam botol kecil dengan ukuran $\pm 10 \mathrm{ml}$ dan ditutup rapat agar senyawa etanol yang terdapat dalam destilat tidak menguap. Dilakukan proses selanjutnya dengan menganalisis sampel yang berupa etanol tersebut dengan menggunakan metode kromatografi gas (GC). Dengan tujuan untuk mengetahui kadar etanol pada tape singkong.

\section{Analisis Kadar Alkohol Pada Tape Singkong Dengan Menggunakan Metode Kromatografi Gas (GC)}

Analisis etanol hasil destilasi tape singkong menggunakan larutan standar etanol dilakukan dengan instrument kromatografi gas (GC). Kromatografi gas adalah teknik kromatografi yang bisa digunakan untuk memisahkan senyawa organik yang mudah menguap. Senyawa yang dapat dipisahkan dengan kromatografi gas sangat banyak, namun ada batasanbatasannya. Senyawa tersebut harus mudah menguap dan stabil pada temperatur pengujian, utamanya dari $50-300{ }^{0} \mathrm{C}$. Jika senyawa tidak mudah menguap atau tidak stabil pada temperatur pengujian, maka senyawa tesebut bisa diderivatisasi agar dapat dianalisis dengan kromatografi gas (Mardoni, dkk., 2007).

Adapun tahapan analisis ini adalah diambil $1 \mu \mathrm{L}$ dari masing-masing larutan singkong dengan syring. Kemudian cuplikan diinjeksikan melalui injektor, suhu injektor diprogram pada suhu $200{ }^{0} \mathrm{C}$ untuk menguapkan fase cair menjadi fase gas. Filtrat cuplikan segera diubah menjadi fase gas dan dibawah oleh aliran gas pembawa menuju kolom.

Suhu kolom diprogram menggunakan mode pemograman suhu. Suhu kolom diprogram pada suhu rendah $100{ }^{0} \mathrm{C}$ agar pemisahan terjadi dengan baik serta untuk mencegah terjadinya kerusakan komponen dalam kolom, suhu maksimum kolom ini adalah $175{ }^{0} \mathrm{C}$. Mode pemograman suhu digunakan agar komponen keluar dengan jarak dari satu 
peak ke peak yang lain tidak terlalu jauh. Jenis kolom yang dipakai adalah kolom porapak yang bersifat polar. Kolom ini dalam memisahkan sampel dengan kecepatan $30 \mathrm{ml} /$ menit.

Di dalam kolom inilah terjadi proses pemisahan senyawa-senyawa dalam cuplikan berdasarkan prinsip "like dissolve like", artinya senyawa-senyawa yang bersifat sama dengan kolom akan tertahan lebih lama, sedangkan untuk senyawasenyawa yang berbeda dengan kolom akan diteruskan menuju detektor dan memiliki retensi yang lebih singkat.

Senyawa etanol yang bersifat sama dengan kolom yakni polar akan tertahan lebih lama dalam kolom dan memiliki waktu retensi yang lebih lama dibandingkan dengan senyawa lain yang bersifat sangat polar.

Suhu detektor diprogram pada suhu $200{ }^{0} \mathrm{C}$ untuk mencegah kondensasi dari cuplikan setelah keluar dari kolom. Detektor yang digunakan adalah (Thermal Conductifity Detector), detektor jenis ini dapat mengukur kemampuan suatu zat dalam memindahkan panas dari daerah panas ke daerah dingin. Semakin besar daya hantar panas maka semakin cepat pula panas dipindahkan. Detektor ini terdiri dari filamen panas tungsen-rhenium yang ditempatkan pada aliran gas yang datang dari arah kolom (Hendayana, S.,2006).

Gas pembawa yang mengalir ke detektor akan terionisasi oleh sumber radiaktif dan menghasilkan elektron, sehingga cuplikan dalam gas pembawa akan menangkap elektron itu dan mengurangi arus listrik. Penurunan arus listrik ini diperkuat dan direkam oleh detektor TCD. Perubahan ini diubah oleh arus listrik yang akan digunakan untuk menghasilkan kromatogram.

Kromatogram hasil kromatografi gas pada gambar 2. menunjukkan bahwa sampel hasil destilasi tape singkong mengandung 2 puncak dengan waktu retensi dan luas area yang berbeda.
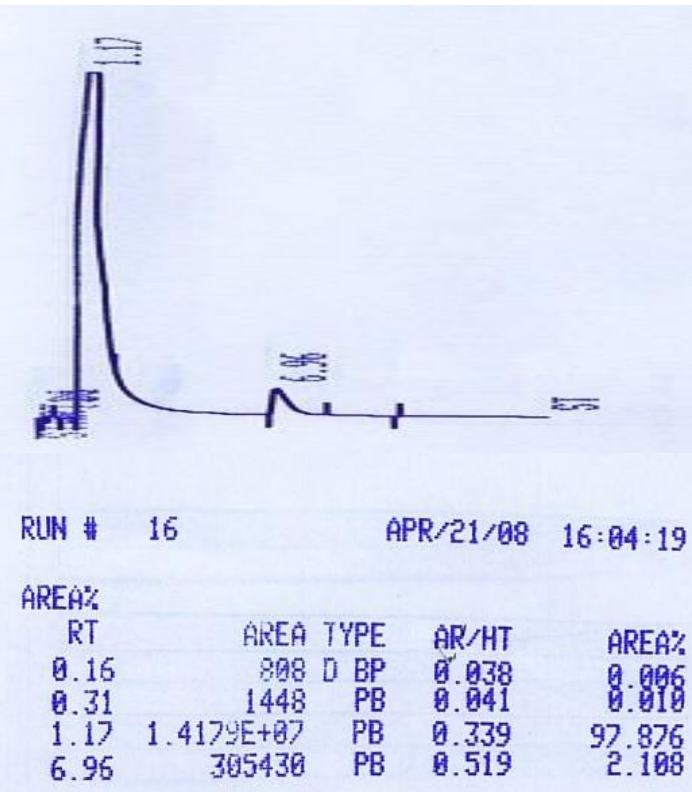

TOTAL AREA $=1.4487 \mathrm{E}+[07$

MUL FACTOR= $1.6060 \mathrm{E}+00$

Gambar 5. Kromatogram Sampel Destilasi Tape Singkong hari ke-1

Gambar 5. Menunjukkan bahwa kromatogram sampel hasil destilasi tape singkong mengandung 2 puncak dengan waktu retensi dan luas area yang berbeda.

\section{Pengaruh Lama Fermentasi Terhadap Kadar Alkohol Tape Singkong}

Hasil rata-rata kadar etanol tape singkong dengan lama fermentasi dapat dilihat pada Tabel 2 .

Tabel 2. Hasil rata-rata kadar etanol tape singkong

\begin{tabular}{|l|c|c|}
\hline No & $\begin{array}{c}\text { Lama } \\
\text { Fermentasi (L) }\end{array}$ & $\begin{array}{c}\text { Rata-rata kadar } \\
\text { etanol (\%) }\end{array}$ \\
\hline 1 & 24 jam & 0,844 \\
\hline 2 & $48 \mathrm{jam}$ & 2,182 \\
\hline 3 & $72 \mathrm{jam}$ & 4,904 \\
\hline 4 & $96 \mathrm{jam}$ & 6,334 \\
\hline 5 & $120 \mathrm{jam}$ & 11,811 \\
\hline
\end{tabular}

Berdasarkan hasil analisis sampel tape singkong dengan parameter lama fermentasi diperolah kadar etanol tertinggi pada fermentasi selama 120 jam yakni $11,811 \%$, sedangkan pada fermentasi 24 
jam kadar etanol sebesar 0,844 \%. Hasil analisis kadar etanol tape singkong menunjukkan kenaikan seiring dengan lamanya waktu fermentasi.

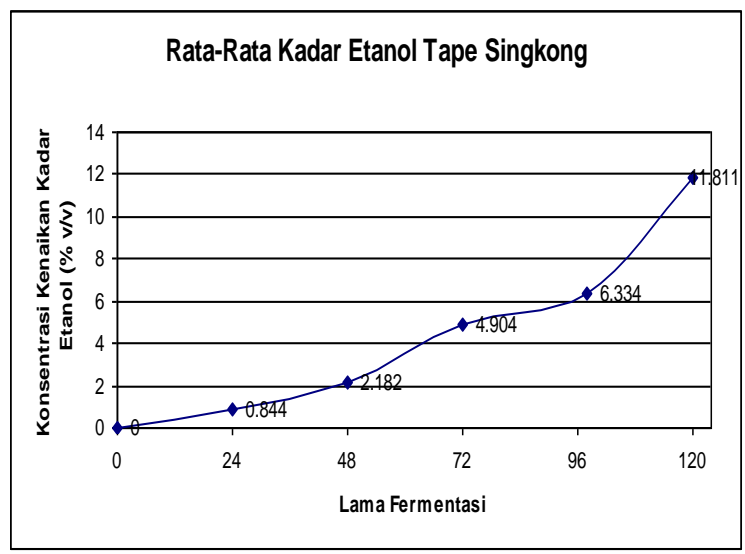

Gambar 6. Rata-Rata Kadar Etanol Tape Singkong

Gambar 6. menunjukkan semakin lama fermentasi berpengaruh sangat nyata ( $p<0,01)$ pada kadar etanol tape singkong. Uji BNT menunjukkan lama fermentasi 120 jam berpengaruh sangat nyata $(\mathrm{p}<0,01)$ pada kadar etanol tape singkong di antara lama fermentasi lainnya.

Dari hasil penelitian ini diketahui kadar etanol tertinggi diperoleh pada hari kelima yaitu fermentasi berlangsung 120 jam. Menurut Prescot dan Daunn dalam Lailatul (2004) menunjukkan bahwa adanya pengaruh lama fermentasi terhadap kadar etanol dalam tape. Dimana dalam selang waktu 1-7 hari kadar etanol dalam tape terus meningkat, sedangkan setelah 7 hari kadar etanol dalam tape menurun.

Hal ini dikarenakan pada hari ke 7 ragi Saccharomyces cerevisiae memasuki fase stasioner, dimana fase ini jumlah mikroba yang hidup sebanding dengan jumlah mikroba yang mati. Dengan demikian semakin berkurang jumlah nutrisi Saccharomyces cerevisiae dan substrat, sehingga Saccharomyces cerevisiae akan semakin menurun dan tidak mampu memproduksi alkohol. Adapun kurva pertumbuhan Saccharomyces cereviseae dapat dilihat pada Gambar 6 (Anonymous, 2008).
Gambar 6 menunjukkan pertumbuhan dari ragi Saccharomyces cereviseae yang mula-mula lambat, lalu cepat, dan akhirnya melambat saat mendekati nilai tertentu. Pada waktu ke 0-6 Saccharomyces cereviseae mvengalami fase adaptasi untuk menyesuaikan dengan substrat dan kondisi lingkungan disekitarnya.

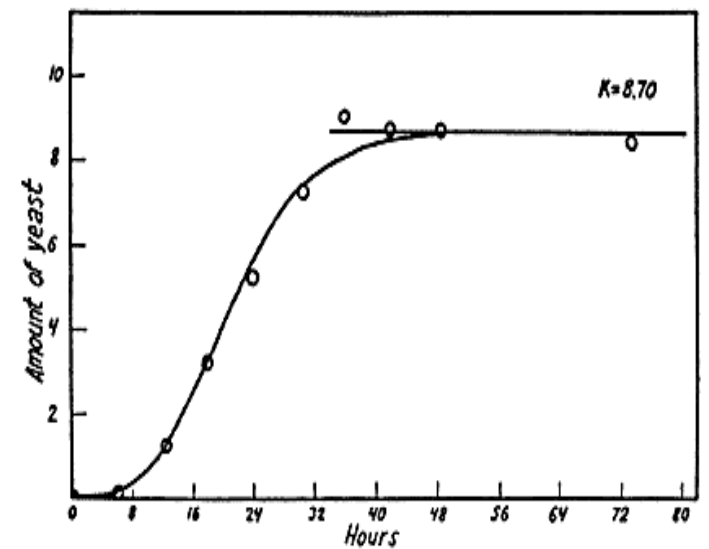

Gambar 6. Kurva Pertumbuhan Saccharomyces cereviseae

Pada waktu ke 7-11 Saccharomyces cereviseae mengalami proses membelah dengan kecepatan masih rendah karena baru selesai tahap menyesuaikan diri, fase ini disebut fase pertumbuhan awal. Pada waktu ke 12-42 Saccharomyces cereviseae membelah dengan cepat dan konstan. Pada waktu ini jumlah Saccharomyces cereviseae meningkat dengan kecepatan eksponensial, fase ini disebut fase logaritmik

Pada waktu ke 43-168 memasuki fase stasioner dimana fase ini jumlah mikroba yang hidup sebanding dengan yang mati. Dengan demikian semakin berkurangnya jumlah nutrisi Saccharomyces cereviseae dan substrat, sehingga Saccharomyces cereviseae akan semakin menurun dengan bertambahnya waktu.

\section{Analisis Hasil Penelitian Dalam Prespektif Islam}

Di abad 21 ini, polemik tentang produk makanan dan minuman yang diharamkan sedang mendapat perhatian dari masyarakat. Ketika teknologi pangan telah 
berkembang sedemikian rupa, berbagai produk makanan instan, makanan cepat saji, restoran sampai jajanan pasar merupakan makanan yang mudah didapat dan sangat rawan dicemari oleh jenis makanan yang tidak halal baik dari segi bahan atau prosesnya. Beberapa contoh makanan dan minuman haram dan berbahaya yang beredar dipasaran seperti MSG dari babi, tuak, bir dan sebagainya.

Allah Swt menciptakan kenikmatan makanan dan minuman tidak lain supaya kita bersyukur atas segala nikmatnikmatNya yang kita rasakan. Seperti dalam Surat Al- Maidah ayat 88 , yaitu:

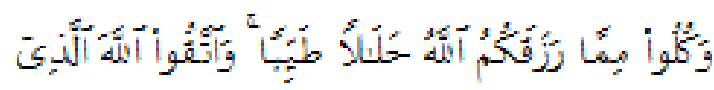

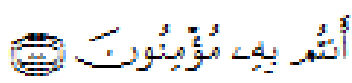

Dan makanlah makanan yang halal lagi baik dari apa yang Allah Telah rezekikan kepadamu, dan bertakwalah kepada Allah yang kamu beriman kepada-Nya.

Dari kandungan ayat tersebut Allah Swt mengharuskan Hamba-Nya untuk memakan makanan yang halal dan toyyib saja. Halal dan toyyib adalah dua kesatuan yang tidak bisa dipisahkan, yang dapat diartikan halal dari segi syariah dan baik dari segi kesehatan, gizi, estetika dan lainnya. Mengenai minuman disebutkan dalam surat Al- Maidah ayat 90-91:

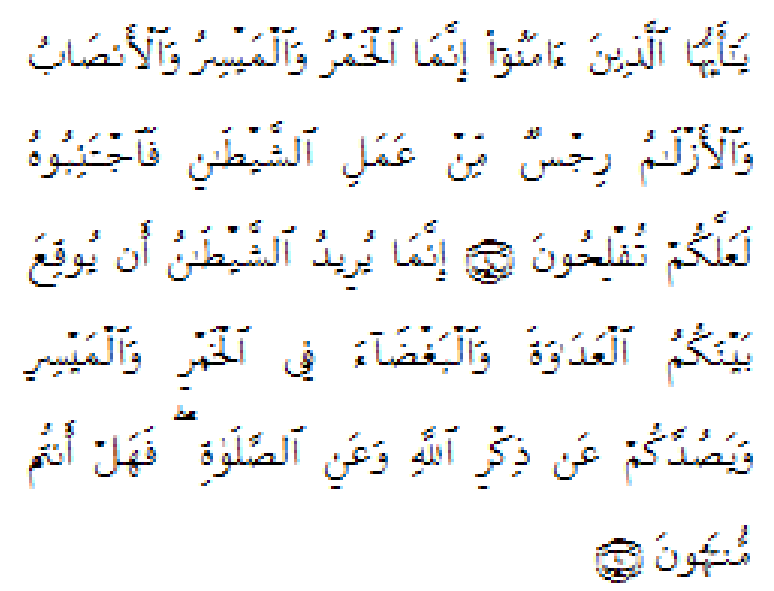

90. Hai orang-orang yang beriman, Sesungguhnya (meminum) khamer, berjudi, (berkorban untuk) berhala, mengundi nasib dengan panah, adalah termasuk perbuatan syaitan. Maka jauhilah perbuatanperbuatan itu agar kamu mendapat keberuntungan.

91. Sesungguhnya syaitan itu bermaksud hendak menimbulkan permusuhan dan kebencian di antara kamu lantaran (meminum) khamer dan berjudi itu, dan menghalangi kamu dari mengingat Allah dan sembahyang; Maka berhentilah kamu (dari mengerjakan pekerjaan itu).

Ayat di atas dengan tegas Islam memandang makanan dan minuman yang memabukkan dikatagorikan sebagai makanan dan minuman yang haram untuk dikonsumsi. Dari hasil kesepakatan MUI, makanan dan minuman yang mengandung alkohol tidak boleh melebihi $1 \%$, sehingga makanan dan minuman yang mengandung kadar alkohol melebihi $1 \%$ termasuk dalam katagori haram untuk dikonsumsi (Apriyantono, 2006 ).

Berdasarkan penelitian yang telah dilakukan, diketahui kadar etanol tape singkong berturut-turut sebesar $0,844 \%$, 2,182\%, 4,904\%, 6,334\%, dan 11,811\%. Tingkat kadar alkohol tape singkong yang mencapai $11.811 \%$ tersebut kurang layak dan sebaiknya tidak dikonsumsi umat muslim.

Melalui ayat 219 surat Al-Baqorah, qur'an secara obyektif bahwa khamer (dan judi) memiliki segi positif dan negatif, dan karena segi negatifnya lebih besar maka hukumnya haram. Pada ayat 90 surat AlMaidah menyebutkan rijs min 'amal alsyaithan (keji sebagai tindakan syaithan) (Ibrahim, Sa'ad, 2008). Rosulullah tidak melihat kepada materi yang digunakan untuk membuat khamer. Beliau melihat kepada pengaruh yang ditimbulkan, yaitu "memabukkan".

Berdasar ayat-ayat dan hadist di atas, dapat dinyatakan 'illat diharamkannya khamer adalah memabukkan. Jadi 'illat (penyebabnya) bukan adanya alkohol 
didalamnya, karena jika 'illat (penyebabnya) adanya alkohol, dalam buah buah-buahpun juga terdapat alkohol. Dengan demikian dapat dinyatakan bahwa (Ibrahim, Sa'ad, 2008):

1. Haram bagi siapa saja jika secara umum memabukkan, baik karena adanya alkohol, maupun tidak, misalnya Anggur obat, anggur kolesom, arak obat dan minumanminuman sejenis.

2. Haram bagi orang-perorangan yang jika mengkonsumsi sesuatu, ia menjadi mabuk, misalnya durian, tetapi tidak bagi orang lain yang tidak mabuk, karena pada umumnya durian tidak memabukkan.

Hingga saat ini belum ada fatwah MUI yang menyebutkan bahwa makanan tape itu haram. Namun, sebagai seorang muslim kita harus berati-hati. Ketika suatu makanan tape telah bisa membuat seorang awam yang tidak pernah mabuk sebelumnya menjadi mabuk, maka makanan tape itu ditetapkan sebagai khamer. Ketika vonis sebagai khamer telah dijatuhkan, maka hukumnya menjadi haram untuk dimakan oleh perorangan tersebut, sedikit atau banyak. Hal ini dikarenakan pada umumnya tape tidak memabukkan.

\section{KESIMPULAN}

Berdasarkan hasil pembahasan dapat disimpulkan bahwa ada pengaruh lama fermentasi terhadap kadar etanol tape singkong. Kadar etanol tape singkong berturut-turut sebesar $0.844 \%, 2.182 \%$, $4.904 \%$, 6.334\%, dan $11.811 \%$. Lama fermentasi 120 jam berpengaruh sangat nyata $(\mathrm{p}<0,01)$ pada kadar etanol tape singkong di antara lama fermentasi lainnya.

\section{DAFTAR PUSTAKA}

Apriyantono, A., 2005, Tape, http:/groups.yahoo.com/group/Hala 1-Baik-Enak/message/5632 diakses 26 Juni 2008.
2006, Minuman Yang

Diharamkan, http://www. halalguide.info/content/view/280/38

/ diakses 22 Oktober 2007.

Anonymous, 2006, Alkohol Dan Problematikanya, http://forum. kotasantri.com/viewtopic.php?t=82 \&postdays $=0$ \&postorder $=$ asc $\&$ start $=5 \& \mathrm{sid}=\mathrm{d} 96024 \mathrm{eb} 43 \mathrm{ca} 1 \mathrm{a} 5787 \mathrm{~d} 999$ d3e156bea7toiut geocities.com/meteorkita/toiut.rtf Hasil Tambahan - GH diakses 27 Mei 2007. , 2007, Umbi Кауu, http:// neocassava.blogspot.com/2007_06_ 01_ archive.html diakses 28 November 2007. 2008, On The Mechanism of Competition In Yeast Cells, http:// www.ggause.com/gfg04. diakses 29 April 2008.

Buckle, K.A., et.all, 1985, Ilmu Pangan, Jakarta: UI-Press.

Hanbali, M., 2001, Pengaruh Lama Fermentasi dan Penambahan Karaginan Terhadap Aspek Kualitas Fisika-Kimia dan Organoleptik Tape Ubi Jalar. Malang: Skripsi tidak diterbitkan. Jurusan Hasil Pertanian Fakultas Pertanian Universitas Brawijaya Malang.

Hendayana, Sumar, 2006, Kimia Pemisaan (Metode Kromatografi dan Elektroforesis Modern), Bandung: PT. Remaja Rosadakarya, hal 32 dan 54.

Ibrahim, Sa'ad, 2008, Alkohol Untuk Kosmetik, Obat, Makanan dan Minuman Dalam Perspektif Hukum Islam, Malang: Makalah disampaikan dalam Olimpiade Kimia Indonesia (OKI) IKAHIMKI Himpunan Mahasiswa Jurusan kimia Fakultas Sains dan Teknologi UIN Malang pada tanggal 1 maret 2008 di Unuversitas Islam Negeri malang.

Irianto, K, 2006, Mikrobiologi: Menguak Dunia Mikroorganisme Jilid 2, 
Bandung: CV. Yrama Widya, hal 214-215.

Tarigan, J., 1988, Pengantar Mikrobiologi

Umum, Jakarta: Departemen

Pendidikan dan Kebudayaan
Direktorat Jenderal Pendidikan Tinggi Proyek Pengembangan Lembaga Pendidikan Tenaga Pendidikan. 